\begin{tabular}{|c|l|}
\hline Title & Suspended particles and their characteristics in water mains : developments of sampling methods \\
\hline Author(s) & Matsui, Y oshihiko; Matsushita, Taku; Y amagishi, Takay uki; Terada, Y oshihiro; Inoue, Takanobu \\
\hline Citation & $\begin{array}{l}\text { Journal of Water Supply : Research and Technology, A QUA, 56(1), 13-24 } \\
\text { https://doi.org/10.2166/aqua.2007.064 }\end{array}$ \\
\hline Issue Date & 2007-02 \\
\hline Doc URL & http://hdl.handle.net/2115/30272 \\
\hline Type & article \\
\hline File Information & JW SRTA 56-1.pdf \\
\hline
\end{tabular}

Instructions for use 


\title{
Suspended particles and their characteristics in water mains: developments of sampling methods
}

\author{
Yoshihiko Matsui, Takayuki Yamagishi, Yoshihiro Terada, Taku Matsushita and Takanobu Inoue
}

\begin{abstract}
$\overline{\text { ABSTRACT }}$
Although advances in water treatment technology have contributed to improved water quality at water treatment plants, treated water is not reaching consumer taps with the same quality. Water quality in service pipes is lower than at the water treatment plants, most likely because rust corrosion particles are generated inside the pipes, accumulated sediments become resuspended or other reasons. In this study, particles suspended in treated water flowing through water mains of various service areas were collected, and their quantity and elemental compositions were analyzed to investigate changes in suspended solid (SS) characteristics over distance and time. In addition to longitudinal changes along water mains, cross-sectional SS changes were investigated by developing a method of directly collecting SS particles flowing through a water main at different vertical locations. SS concentrations and the percentages of inorganics and iron in SS increased as water traveled toward the dead end of a main. Vertical differences of SS in the main cross section were also observed: SS concentrations in the upper part were higher than those in the middle and lower parts. The higher percentages of inorganics and iron in the upper part suggested that scaling in the upper part of the main, which had a stagnant area, caused iron particles to be released into the stream. Temporal variations in SS concentrations were observed for water flowing through the middle and lower parts of the main cross section. SS concentrations increased with increased flow rates, indicating resuspension of sediment at the bottoms of the mains. Overall, ss concentrations, their temporal variations, their cross-sectional changes and the elemental compositions of SS in water were different in various water service areas, and these characteristics could be useful in determining the origin of SS particles in drinking water.
\end{abstract}

Key words | distributed water, residuals, sediment, water quality

\section{$\overline{\text { INTRODUCTION }}$}

A great deal of research and development has been conducted on water treatment, and advances in water treatment technology have contributed to improved water quality at water treatment plants. It is, however, well known that water in a distributing main does not necessarily have the same quality, and is generally lower in quality, than the original treated water. In water mains, some suspended particles may be generated by precipitation of metals such as manganese or iron (Sly et al. I990); from biological

growth; by formation of rust owing to corrosion phenomena such as scale; or by the resuspension of accumulated deposits or precipitated metals, leading to the turbidity detected by consumers in tap water (Sly et al. 1989). Particulate matter can settle and accumulate on the bottom of a main at times of low demand and consequent very low flow velocity, such as around midnight. These particles become resuspended when flow rates increase, which occurs frequently because the water demand varies from

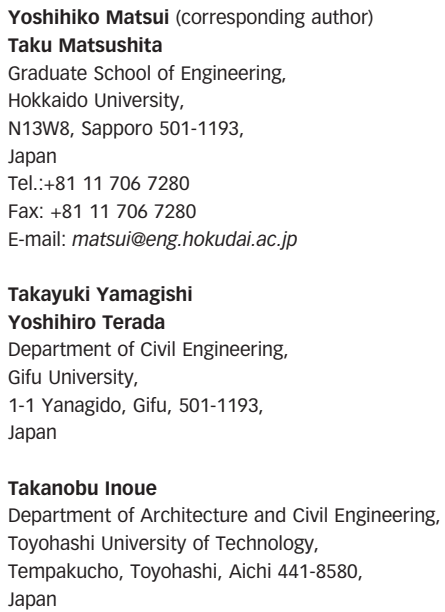


year to year, season to season, day to day, and hour to hour. A survey conducted in Japan (Japan Water Research Center 2005) revealed that $77 \%$ of water suppliers receive customer complaints about tap water quality, and $81 \%$ of the customer complaints mention turbid water (including red water) and large extraneous substances in the water. Water suppliers believe that these substances originate from innersurface corrosion in pipes (42\%), fragmentation of plastic linings (13\%), precipitation and suspension of iron, manganese and aluminum (18\%), and introduction by construction work (e.g. installation of water main, connection of a service pipe to a water main, etc.) (19\%).

Although suspended particles likely have different characteristics, depending on generation/formation mechanisms, limited light has been shed on the subject of suspended particles and their characteristics in water flowing through water mains and service pipes. Problematic concentrations of suspended solid (SS) (i.e. exceeding turbidity limits for water suppliers and unpleasant tap water for consumers) can be reduced by hydraulically flushing the distribution system, but this method uses and wastes huge amounts of water. Water suppliers examine particulate matter visually by microscope or have it chemically analyzed for identification in response to customer complaints. However, very little is known about the chemical nature of SS or suspended particles at problematic or organoleptic or lower concentrations in service pipes and water mains (Gauthier et al. 200I). Gauthier et al. used a parallel filtration system to collect suspended particles in tap waters and then conducted mineral elemental analysis as well as gravimetric analysis of suspended solids (SS) retained on filters. They postulated that this type of characterization can be helpful in quantifying SS in a way other than turbidity assessment or particle counting (American Water Works Association 1999), providing information regarding treatment plant and distribution system performance. Using particle counter and elemental analysis of SS collected by filters, Inoue $e t$ al . (2004) analyzed the elemental compositions and particle size distributions of SS in raw, treated, and distributed waters in order to understand particle behavior during the water treatment and distribution process. They reported that percentages of organics and aluminum were higher after water treatment than before, and that total SS concentrations in distributed waters were higher than those in treated water, primarily owing to the increase of inorganics, including iron. They also reported that the carbon in the SS was mostly organic, and that the fraction of inorganic carbon was very low. SS in water flowing through a water main and its characteristics, however, has never been examined by withdrawing water directly from a water main without using a service pipe, etc.

This paper describes methods of collecting water samples containing particles directly from water flowing through a main. The quantities and chemical compositions of collected SS samples were analyzed by elemental and gravimetric analysis, and the changes in SS characteristics with distance traveled, over time, and vertically in cross section were evaluated for the first time.

\section{SAMPLING AND ANALYTICAL METHODS}

\section{Filters and filtration systems}

Suspended particles were collected on inorganic and organic filters using a 6- or 8-line filtration system (Figures 1 and 2) with quartz membrane filters (QM-A, $0.6 \mu \mathrm{m}$ nominal pore size, Whatman) and PVDF membrane filters (SVWG04700, $5 \mu \mathrm{m}$ nominal pore size, Millipore). The inorganic quartz filter type was selected for most analyses because of its negligible metal and organic contents. Prior to filtration, filters were rinsed with $0.1 \mathrm{~N}$

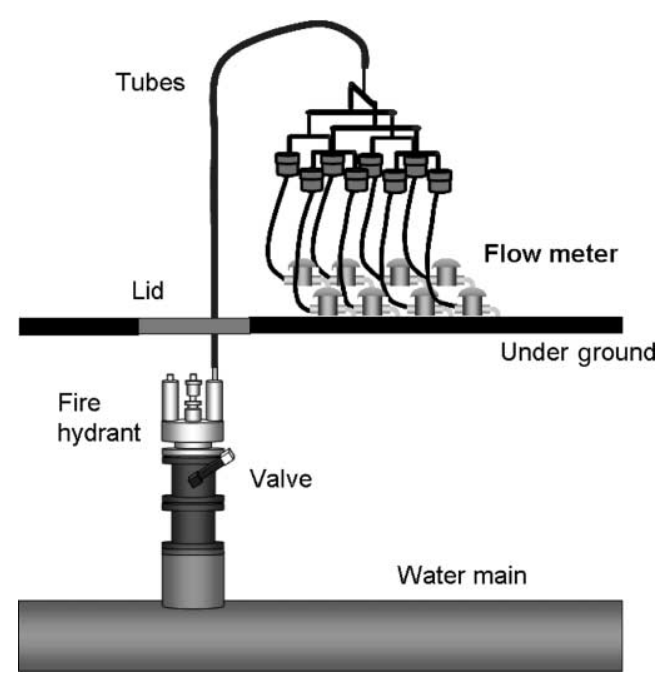

Figure 1 | Sampling Method 1 with an 8-line filtration system. 


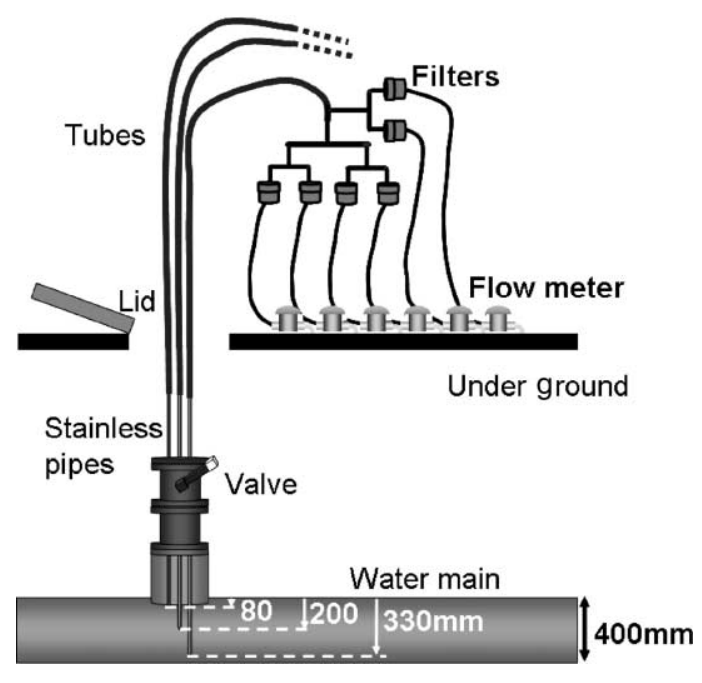

Figure 2 | Sampling Method 2 with a 6-line filtration system (an application to a $400 \mathrm{~mm}$ main)

nitric acid and pre-combusted at $550^{\circ} \mathrm{C}$ in a muffle furnace for $6 \mathrm{~h}$. The organic PVDF membrane filters were used for the analysis of silicon in retained SS. However, the organic membranes could filter less water than the inorganic membranes, and the ratios of filtrate volume for organic and inorganic membranes varied from 30 to $80 \%$, probably depending on particulate sizes; thus silicon content measured using organic membranes could not be directly compared with other contents measured using inorganic membranes. Owing to the large filterability difference between organic and inorganic membrane filters, data for silicon were not substantially used in the results and discussion. The filters were placed in the filter holders (PP47, Toyo Roshi Kaisha, Ltd., Tokyo) and the filtration system was connected to a fire hydrant or a stainless steel tube inserted into a street water main (Figures 1 and 2) and water flowing through the street water main was sampled directly (not through a service line), thereby minimizing the effect of detention in service pipes on water quality. Sampling Method 1, using a fire hydrant (Figure 1), was quite simple and was employed until the year 2004. Before filtration began, about $0.7-1.0 \mathrm{~m}^{3}$ of the first water collected was discarded in order to completely purge stagnant water in the fire hydrant. Sampling Method 2 (Figure 2), which was devised in late 2004, involved collecting samples from water flowing at defined crosssectional locations in a street water main. This method was developed based on the idea that flowing water could not be cross-sectionally well mixed and that the water quality could not be cross-sectionally homogeneous. In addition, the water quality deterioration owing to resuspension of bottom deposits could be better detected in water samples collected near the bottom of the main than from the top of the stream as in Sampling Method 1.

The total volume filtered for each filter line was measured using a water meter (SD13, Aichitokeidenki Co., Nagoya, Japan) for a flow rate $>20 \mathrm{~L} / \mathrm{h}$, the lower measurement limit of the water meter. When a flow rate was below this level, batch volumetric measurements were collected using $10 \mathrm{~L}$ polyethylene tanks and $1 \mathrm{~L}$ graduated cylinders. Filtration durations were about $3-4 \mathrm{~h}$, and the amount of water filtered was about $200-900 \mathrm{~L}$ for a quartz filter and 60-400 L for an organic membrane filter, unless the filter became heavily clogged, causing the filtration rate to decrease dramatically. The withdrawal of water for sampling had only a minimal effect on the flow rate in a water main. The ratios of flow rates during sampling to flow rates in the water main were mostly unknown because flow rates in mains are rather difficult to measure. During the sampling event of December 2004, when water samples were withdrawn from three vertical locations in the main cross section using Sampling Method 2, however, the flow rates in the mains were actually measured by inserting a velocity meter through a fire hydrant and the measurement revealed that the total withdrawal flow rates for the three samples accounted for only $4 \%$ of the flow rates in the mains in daytime and $17 \%$ at midnight. When the other sampling events were conducted, using Sampling Method 1 with a single water withdrawal and usually in the daytime, the ratios of the sampling flow rates to the flow rates in the water mains were less than $10 \%$. These ratios are negligibly small when compared with the very large daily fluctuations in flow rates in a water main, and we assumed that the sampling activity itself did not affect the water quality in the water main. Following filtration, the filters were transferred to a crucible, dried at $105^{\circ} \mathrm{C}$ and stored in a desiccator until analysis.

\section{Analytical method}

Gravimetric analyses were conducted by weighing the filters after drying at $105^{\circ} \mathrm{C}$ and after combustion in a muffle 
furnace at $550^{\circ} \mathrm{C}$ for $30 \mathrm{~min}$, which provided the total suspended solids (TSS) and volatile suspended solids (VSS) concentrations. The fixed suspended solids (FSS) concentration was calculated by subtracting VSS from TSS (American Water Works Association 1998). Filters retaining SS were digested in a pressure-resistant container at $180^{\circ} \mathrm{C}$ for $2 \mathrm{~h}$ after the additions of $15 \mathrm{~mL}$ of $1: 1$ nitric acid and $3.6 \mathrm{~mL}$ of $30 \%$ hydrogen peroxide (Rodushkin et al. 2000). Elemental analyses were conducted for the resulting solution by ICP-MS (7500i, Agilent Technologies Japan, Tokyo) and the concentrations of eight elements ( $\mathrm{Mg}, \mathrm{Al}$, $\mathrm{Ca}, \mathrm{Mn}, \mathrm{Fe}, \mathrm{Cu}, \mathrm{Zn}, \mathrm{Pb}$ ) were quantified. The total carbon and nitrogen contents were determined with an NC analyzer (Sumigraph NC-800, Sumika Chemical Analysis Service, Osaka, Japan). Silicon concentration in the solution was determined by the molybdosilicate method (Wang et al. I997; Ödman et al. I999 ). Pound Sediment, an Environmental Certified Reference Material (Laboratory of Intellectual Fundamentals for Environmental Studies, National Institute for Environmental Studies, Japan), whose elemental composition was given by the supplier, was used as an analytical standard to check decomposition and recovery rate. The ratios of $\mathrm{Fe}, \mathrm{Mn}, \mathrm{Al}, \mathrm{Ca}$ and $\mathrm{Si}$ were 98, 78, 109, 92 and 100\%, respectively, and almost all the elements included in SS could be quantified.

\section{Sampling}

Locations and dates of each sampling event are presented in Tables 1 and 2. Suspended particle sampling and analysis were conducted in 2003 and 2004 at four water service areas in two cities. In 2003, sampling events were conducted at three service areas (designated as NA, NB and NC) in Nagoya City, Japan (Figure 3), using Sampling Method 1. In each service area, we selected five or six sampling sites, where water samples were withdrawn through fire hydrants. Sampling sites in each service area were within about $5 \mathrm{~km}$ of the trunk main (NA, NB) or water distribution tank (NC). In September 2004, sampling events were conducted again in service area NC. In October 2004, sampling at one NC site was repeated every $3 \mathrm{~h}$ for about one day to assess temporal variations in water quality. In December 2004, sampling was repeated every $3 \mathrm{~h}$ for about one day using Sampling Method 2, by which water samples were withdrawn from different cross-sectionally vertical locations within the main. During this sampling event, water flow velocity was measured at the water main $100 \mathrm{~m}$ upstream from the sampling point by a velocity meter inserted into the vertical center of the main. Besides these Nagoya City sampling sites, two sites in Wakayama City were selected, and sampling events were conducted in 2004 using Sampling Method 2.

\section{RESULTS AND DISCUSSION}

\section{sS changes along water main}

As shown in Figures 4 and 5, measurements along the distribution pipelines indicate that SS concentrations in water samples increased two- or threefold with distance from the trunk main, i.e. toward the dead-end location of the distribution service area. The elemental analysis found that aluminum, iron and carbon were major elements constituting the SS (in the figures hereafter aluminum was supposed to be present as the form of $\mathrm{Al}(\mathrm{OH})_{3}$, iron as $(\mathrm{FeOOH})$ and manganese as $\mathrm{MnO}_{2} \bullet \mathrm{H}_{2} \mathrm{O}$ (Gauthier et al. 200I)). Silicon was also detected in small, though not negligible, amounts $(2-10 \%)$, but the percentages of silicon are not shown in the figures because of the large filterability difference between organic and inorganic membrane filters, as described in Sampling and Analytical Methods. The elemental analysis of the inorganic filters showed that carbon, nitrogen and aluminum concentrations did not increase, but an increase was observed in iron concentrations, indicating the production of corrosion particles in water mains close to dead ends. According to the previous study in which total carbon and organic carbon were separately analyzed by a TOC analyzer with a solid sample combustion unit (Inoue et al. 2004), the carbon in SS was mostly in organic form. The $\mathrm{C} / \mathrm{N}$ ratios of SS (6.4 in the previous study (Inoue et al. 2004) and 5.1-7.7 in the present study) suggest that the organic substances mostly originated from organic seston such as bacteria. Therefore, bacterial regrowth in the water mains might not have contributed much to the increase in SS. The SS increase was attributed to the increase in inorganic suspended particles primarily comprising iron and its compounds. Actually, as shown in 
Table 1 | Sampling points

\begin{tabular}{|c|c|c|c|c|c|c|c|c|c|}
\hline $\begin{array}{l}\text { Designation } \\
\text { of sampling } \\
\text { site }\end{array}$ & $\begin{array}{l}\text { Diameter of } \\
\text { water main } \\
(\mathrm{mm})\end{array}$ & $\begin{array}{l}\text { Detention time from a } \\
\text { distribution reservoir } * * \text { (h) }\end{array}$ & $\begin{array}{l}\text { Distance from a trunk } \\
\text { main or a water } \\
\text { distribution tank }(\mathrm{km})\end{array}$ & $\begin{array}{l}\text { Year of } \\
\text { installation }\end{array}$ & $\begin{array}{l}\text { Straight } \\
\text { water main }\end{array}$ & Special fittings & $\begin{array}{l}\text { Fire } \\
\text { hydrant }\end{array}$ & Service area & City \\
\hline NA1 & 400 & 8.2 & 0.13 & 1989 & $\begin{array}{l}\text { Cement } \\
\text { mortar } \\
\text { lined }\end{array}$ & $\begin{array}{l}\text { Mostly epoxy-resin } \\
\text { lined and the remaining } \\
\text { is unlined }\end{array}$ & Unlined & Minatoku & Nagoya \\
\hline NA2 & 400 & 8.9 & 1.44 & 1969 & & & & & \\
\hline NA3 & 150 & Unknown $*$ & 3.81 & 1970 & & & & & \\
\hline NA4 & 400 & 10.3 & 3.90 & 1992 & & & & & \\
\hline NA5 & 100 & Unknown * & 4.06 & 1987 & & & & & \\
\hline NA6 & 100 & Unknown $*$ & 5.00 & 1976 & & & & & \\
\hline NB1 & 400 & 3.1 & 0.12 & 1984 & $\begin{array}{l}\text { Cement } \\
\text { mortar } \\
\text { lined }\end{array}$ & Epoxy-resin lined & Unlined & Jimokuji & \\
\hline NB2 & 400 & 4.9 & 1.08 & 1984 & & & & & \\
\hline NB3 & 300 & 5.8 & 1.79 & 1984 & & & & & \\
\hline NB4 & 150 & Unknown $*$ & 3.18 & 1985 & & & & & \\
\hline NB5 & 100 & Unknown $*$ & 3.76 & 1988 & & & & & \\
\hline NB6 & 100 & Unknown $*$ & 3.89 & 1985 & & & & & \\
\hline $\mathrm{NC} 1$ & 400 & 1.6 & 0.72 & 1978 & $\begin{array}{l}\text { Cement } \\
\text { mortar } \\
\text { lined }\end{array}$ & $\begin{array}{l}\text { Mostly epoxy-resin lined; } \\
\text { the remainder is unlined }\end{array}$ & Unlined & Moriyama & \\
\hline $\mathrm{NC} 2$ & 400 & 5.2 & 2.53 & 1990 & & & & & \\
\hline NC3 & 400 & 5.4 & 2.61 & 1990 & & & & & \\
\hline NC4 & 400 & 6.0 & 2.82 & 1994 & & & & & \\
\hline NC5 & 400 & 6.3 & 2.92 & 1994 & & & & & \\
\hline NC6 & 400 & 6.6 & 3.04 & 1994 & & & & & \\
\hline NC7 & 400 & 7.0 & 3.18 & 1994 & & & & & \\
\hline NC8 & 400 & 7.4 & 3.30 & 1991 & & & & & \\
\hline NC9 & 400 & 18.2 & 4.67 & 1983 & & & & & \\
\hline NC10 & 100 & Unknown $*$ & 5.17 & 1988 & & & & & \\
\hline NC11 & 100 & Unknown $*$ & 5.27 & 1985 & & & & & \\
\hline W1 & 150 & Unknown $*$ & 3.61 & 1982 & $\begin{array}{l}\text { Cement } \\
\text { mortar } \\
\text { lined }\end{array}$ & Cement mortar lined & Unlined & Minato & Wakayama \\
\hline W2 & 150 & Unknown * & 3.20 & 1986 & $\begin{array}{l}\text { Cement } \\
\text { mortar } \\
\text { lined }\end{array}$ & unlined & Unlined & Nango & \\
\hline
\end{tabular}




\begin{tabular}{|c|c|c|c|c|}
\hline Designation of sampling event & Date & Sampling sites & Method & Time \\
\hline S1 & December 11, 2003 & NA1 - NA3 & Sampling Method 1 & 9:30 AM-12:20 PM \\
\hline S2 & December 11, 2003 & NA4-NA6 & Sampling Method 1 & 12:40 PM-4:30 PM \\
\hline S3 & October 17, 2003 & NB1 - NB3 & Sampling Method 1 & 9:30 AM-12:20 PM \\
\hline S4 & October 17, 2003 & NB4-NB6 & Sampling Method 1 & 12:40 PM-4:30 PM \\
\hline S5 & October 14, 2003 & $\mathrm{NC} 1, \mathrm{NC} 5, \mathrm{NC} 8$ & Sampling Method 1 & 9:30 AM-12:20 PM \\
\hline S6 & October 14, 2003 & NC9, NC10 & Sampling Method 1 & 12:40 PM-4:30 PM \\
\hline S7 & September 27, 2004 & $\mathrm{NC} 2-\mathrm{NC} 4$ & Sampling Method 1 & 9:30 AM-12:20 PM \\
\hline S8 & September 27, 2004 & NC5-NC7 & Sampling Method 1 & 12:40 PM-4:30 PM \\
\hline S9 & October 2526, 2004 & NC5 & Sampling Method 1 & 10:20 AM-9:35 AM (every $3 \mathrm{~h}$ ) \\
\hline S10 & December 1617, 2004 & NC5 & Sampling Method 2 & 12:30 PM-1:25 PM (every $3 \mathrm{~h}$ ) \\
\hline S11 & November 12, 2004 & $\mathrm{~W} 1, \mathrm{~W} 2$ & Sampling Method 2 & 12:50 PM-11:50 AM (every $15 \mathrm{~min}$ \\
\hline
\end{tabular}

Figures 6 and 7, the percentages of FSS (equivalent to inorganic solids) increased as SS concentrations increased toward the water mains' dead ends. Gauthier et al. (200I) also found that particulate concentrations were high at the dead end of a water main. However, they commented that the increase reflected increases in both organic and mineral contents. In contrast, we found that the SS increase reflected mainly inorganic solids. The discrepancy between our results and those of Gauthier et al. might result from differences in bacterial regrowth potential or concentrations of disinfectant chlorine in the water. The Japan Water Research Center (2005) also reported that the concentrations of SS in water mains samples collected at locations close to dead ends (i.e. with slow flow rates) were higher than those collected from water mains with higher flow rates, irrespective of whether the water mains were cementmortar lined or unlined. The ratios of FSS to TSS were also higher for the slow flow rate locations than for the higher flow rate locations. The ages of water mains in our sampling sites were between 10-34 years old, but they did not have a similar age in each service area (water mains of different ages were laid even in the same service area, see Table 1). Any clear relationship between SS concentrations and ages of water mains was not found. A possible reason for this was that the straight mains in the service area studied were all cement-mortar lined and most of the special fittings were all epoxy-resin lined, so that they did not yield corrosion products depending on their ages.

As shown in Figures 4 and 5, concentrations of chlorine, which was added at the water treatment plant, over the reach of the main decreased by $25 \%$ at most, and no substantial chlorine concentration decrease was observed. The detention time between the first sampling site (NA1) and the fourth sampling site (NA4) was $2.1 \mathrm{~h}$. The detention time between NB1 and NB3 was $2.7 \mathrm{~h}$. Although these time periods were obtained by Nagoya Waterworks \& Sewerage Bureau, which conducted a steady-state hydraulic analysis of the service area distribution network, including surrounding ones, and therefore the instantaneous distributions of pressure and flow at the sampling date and time were not accurately recorded, the detention times between sampling sites should have been too short to substantially reduce chlorine concentrations. Nonetheless, water quality in terms of SS concentrations and compositions changed appreciably. Although the SS concentrations measured in our research were far below the 


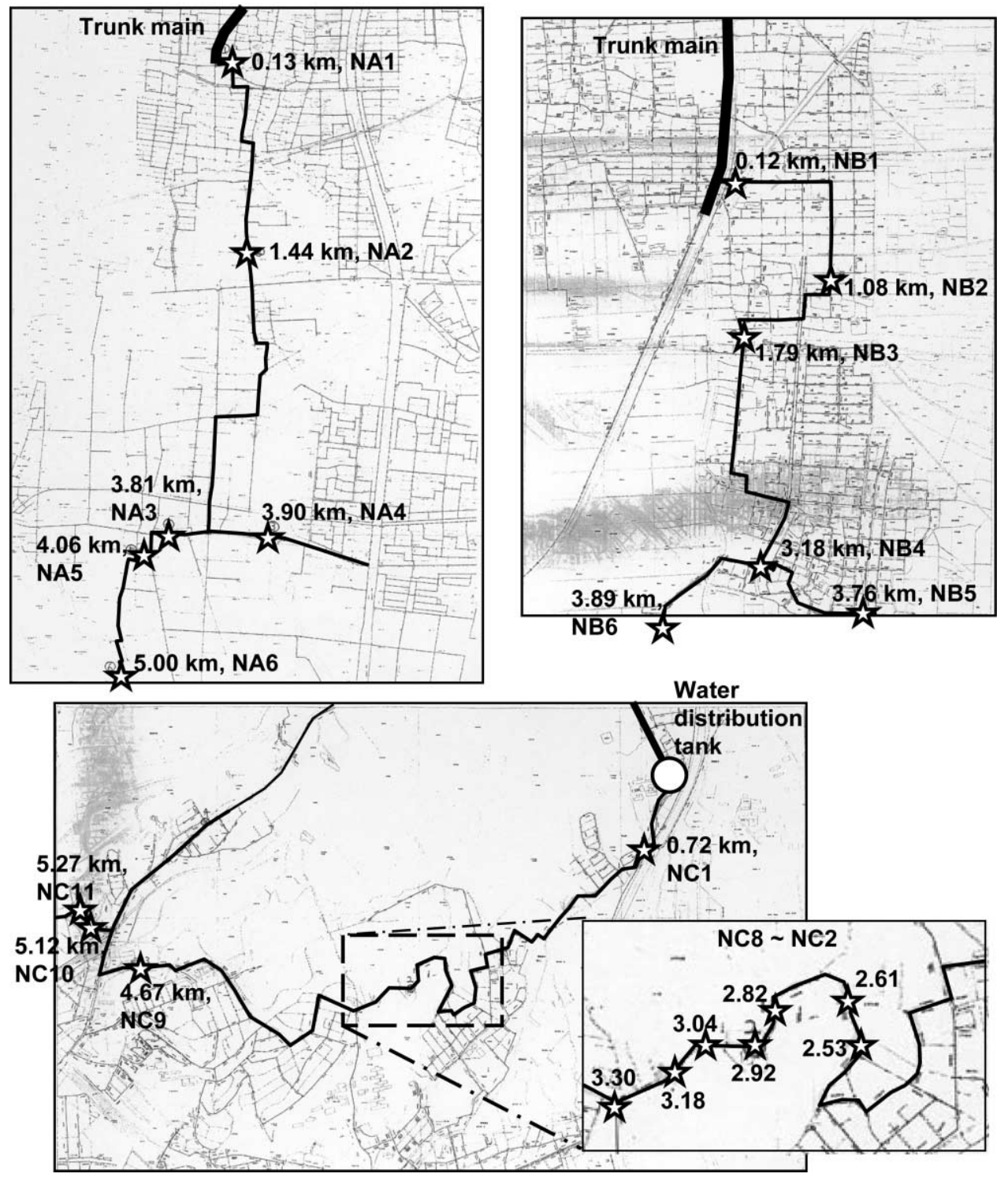

Figure 3 | Locations of sampling points. Upper left: service area NA (Minatoku), upper right: service area NB (Jimokuji), and lower: service area NC (Moriyama).

drinking water quality standard and were not at all problematic for water suppliers and for consumers, the results suggest that changes in SS concentrations and elemental compositions could be better and more sensitive indicators than residual chlorine to measure water quality deterioration in distribution networks.

A simple, monotonic increase in SS concentrations along the water main flow direction was not observed in service area NC. As shown in Figure 8, SS concentrations increased once at site NC5, $2.92 \mathrm{~km}$ from the water distribution tank, and then decreased at NC3, after which concentrations increased with distance. As shown in Figure 10, SS concentrations also increased at site NC5. At site NC5, the increase in SS was caused by the increase in iron content, suggesting the production of corrosion particles there or immediately upstream. The percentages of FSS in SS also increased there (Figures 9 and 11).

\section{SS changes over time}

At the NC5, samples were collected about every $3 \mathrm{~h}$ for about one day, and temporal changes of SS concentrations 


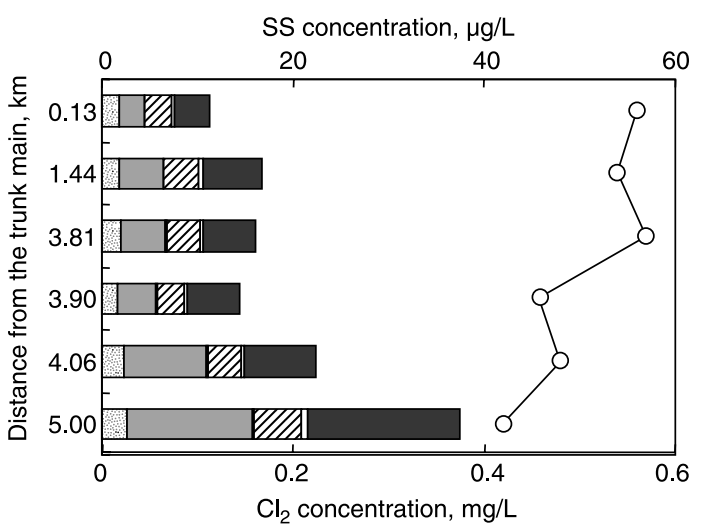

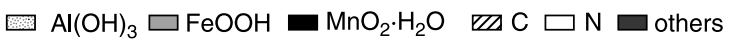
$-\mathrm{O}-\mathrm{Cl}_{2}$ concentration

Figure 4 | SS concentrations, their elemental compositions and chlorine residuals in service area NA (sampling events S1 and S2).

and compositions were observed. Contrary to our expectation, temporal variations in concentrations were not observed, as shown in Figure 12. We had expected SS concentrations to increase in the morning and evening owing to the high flow rates in the water main at those times, which would have caused the resuspension of sediments deposited during low flow rate periods.

For the next survey at NC5, we devised a new sampling method, Sampling Method 2, which enabled withdrawal of water samples from different vertical heights in a main cross section. The resuspension of sediment at the bottom of the main could be sensitively detected by measuring SS concentrations in water flowing near the bottom. Water

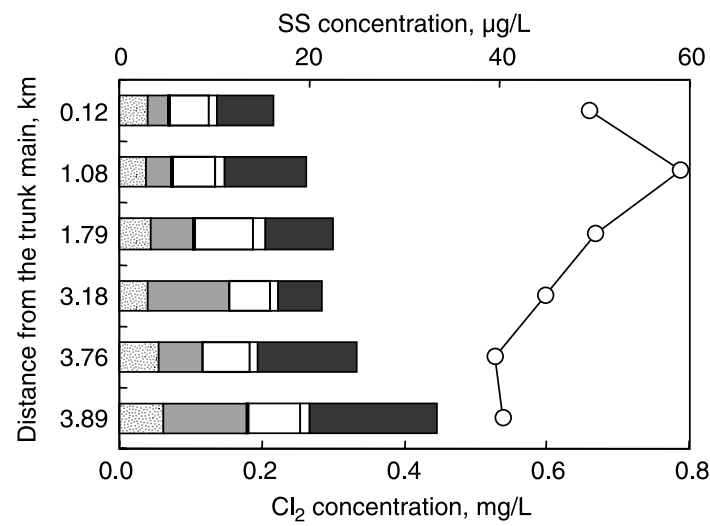

$$
\begin{array}{r}
\mathrm{Al}(\mathrm{OH})_{3} \square \mathrm{FeOOH} \square \mathrm{MnO}_{2} \cdot \mathrm{H}_{2} \mathrm{O} \square \mathrm{C} \square \mathrm{N} \square \text { others } \\
-\mathrm{O}-\mathrm{Cl}_{2} \text { concentration }
\end{array}
$$

Figure 5 | SS concentrations, their elemental compositions and chlorine residuals in service area NB (sampling events S3 and S4).

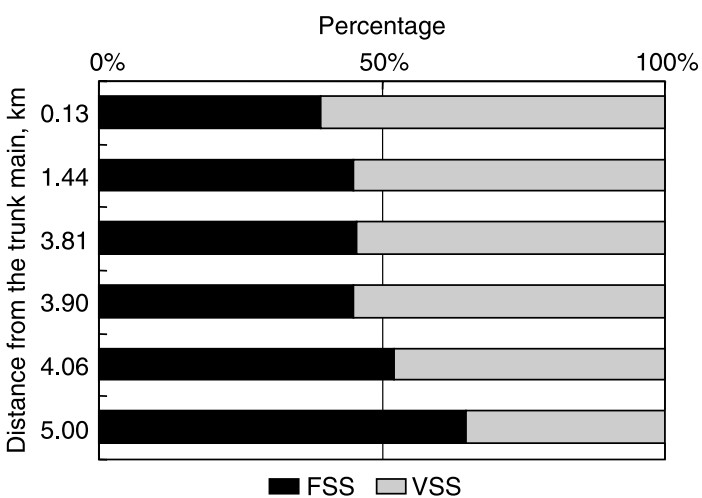

Figure 6 Percentages of inorganic SS (FSS) and organic SS (VSS) in service area NA (sampling events S1 and S2).

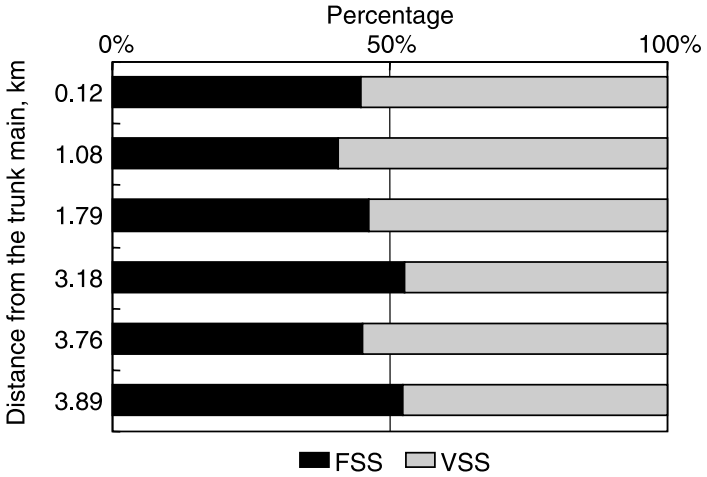

Figure 7 | Percentages of inorganic SS (FSS) and organic SS (VSS) in service area NB (sampling events S3 and S4).

samples were withdrawn from three different vertical heights in the $400 \mathrm{~mm}$ water main: an upper location ( $80 \mathrm{~mm}$ from the top), a middle location (equidistant from the top and bottom) and a lower location (70 $\mathrm{mm}$ from the

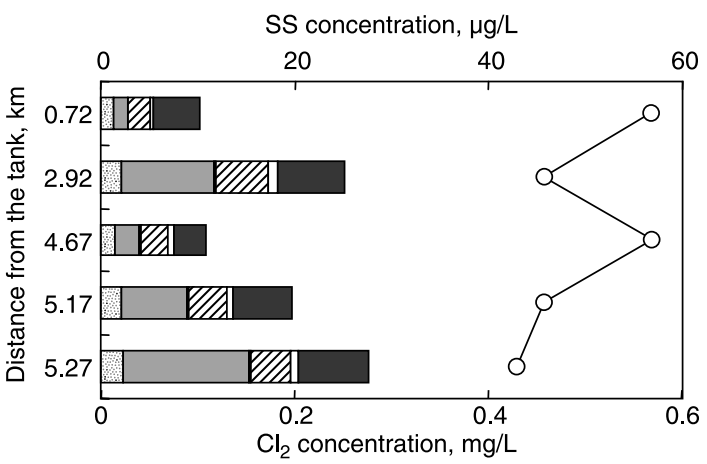

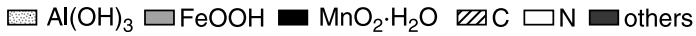
$-\mathrm{O}-\mathrm{Cl}_{2}$ concentration

Figure 8 SS concentrations, their elemental compositions and chlorine residuals in service area NC (sampling events S5 and S6). 


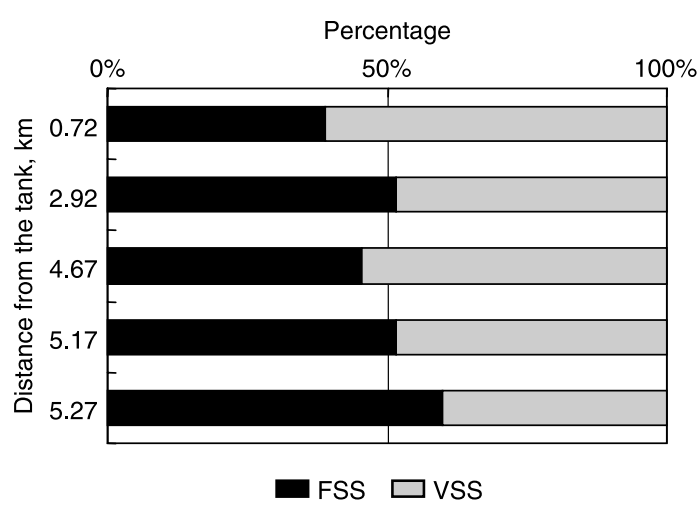

Figure 9 | Percentages of inorganic SS (FSS) and organic SS (VSS) in service area NC (sampling events S5 and S6).

bottom), as shown in Figure 2. As shown in Figure 13, temporal changes in SS concentrations were, in fact, observed for the middle and lower locations. The concentration in the upper location stayed approximately constant for the first three samplings, rose at the fourth sampling (from 22:00 to 01:00), and thereafter stayed approximately constant again. We believe that the rise observed in the upper location was caused by the increased SS concentrations in the inflow water released to the water main from the water distribution tank at about this time. The SS concentrations in the middle and lower sections also seemed to increase at the same time period. Overall, the results of Figures 12 and 13 indicate that SS concentrations in the middle and lower sections changed with time, but

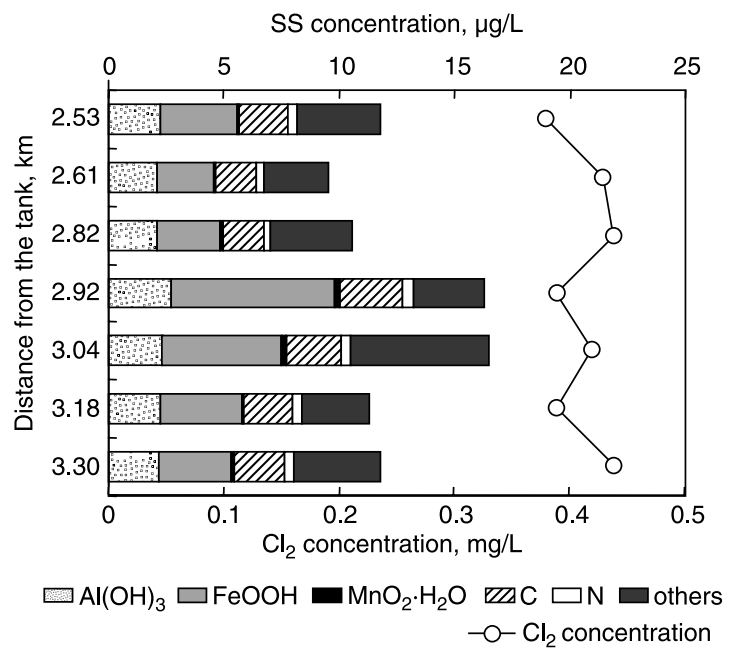

Figure 10 | SS concentrations, their elemental compositions and chlorine residuals at sampling sites NC2-NC8, 2.53-3.30 km from the water distribution tank (sampling events S7 and S8).

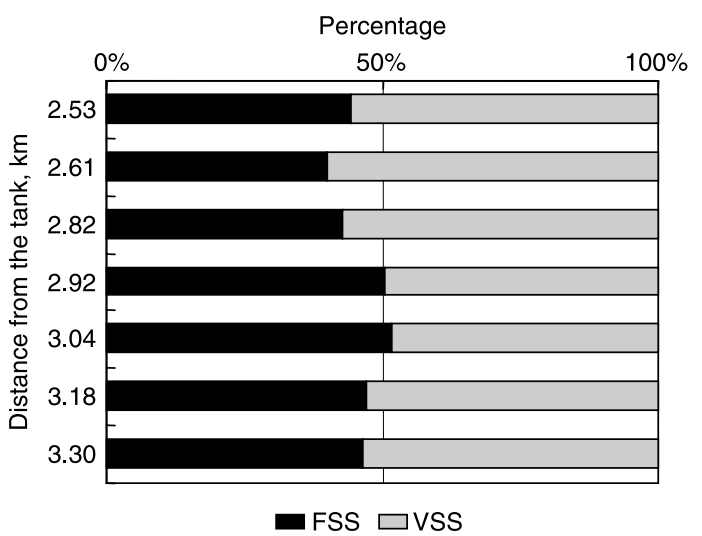

Figure 11 Percentages of inorganic SS (FSS) and organic SS (VSS) at sampling sites $\mathrm{NC2}-\mathrm{NC} 8,2.53-3.30 \mathrm{~km}$ from the water distribution tank (sampling events $\mathrm{S} 7$ and S8).

that SS concentrations in the upper section did not (if SS concentrations in the inflow water to the water main did not change). Figure 14 shows temporal variations in flow rate measured $100 \mathrm{~m}$ upstream from the sampling site. Increases and decreases in SS concentrations in the lower and middle locations corresponded to the flow rates, indicating that SS concentration increases were caused by resuspension of sediment owing to the increased flow rate.

Similar temporal changes in SS concentrations were observed at sampling sites W1 and W2, where water samples were withdrawn from the centers of water mains using Sampling Method 2 about every $4 \mathrm{~h}$ for about one day (unless the filter became clogged; we did not collect samples

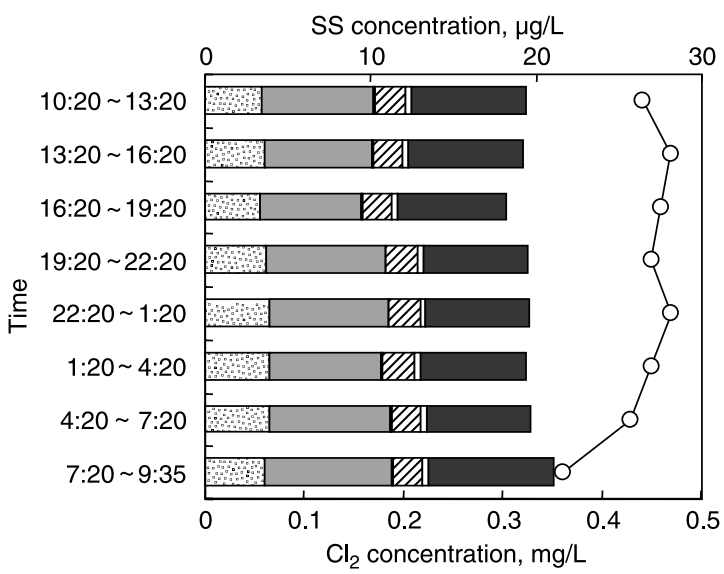

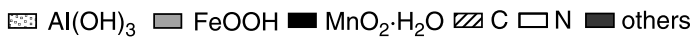

$-\mathrm{O}-\mathrm{Cl}_{2}$ concentration

Figure 12 Temporal changes in SS concentrations, their elemental compositions and chlorine residuals at sampling site NC5 (sampling event S9). 

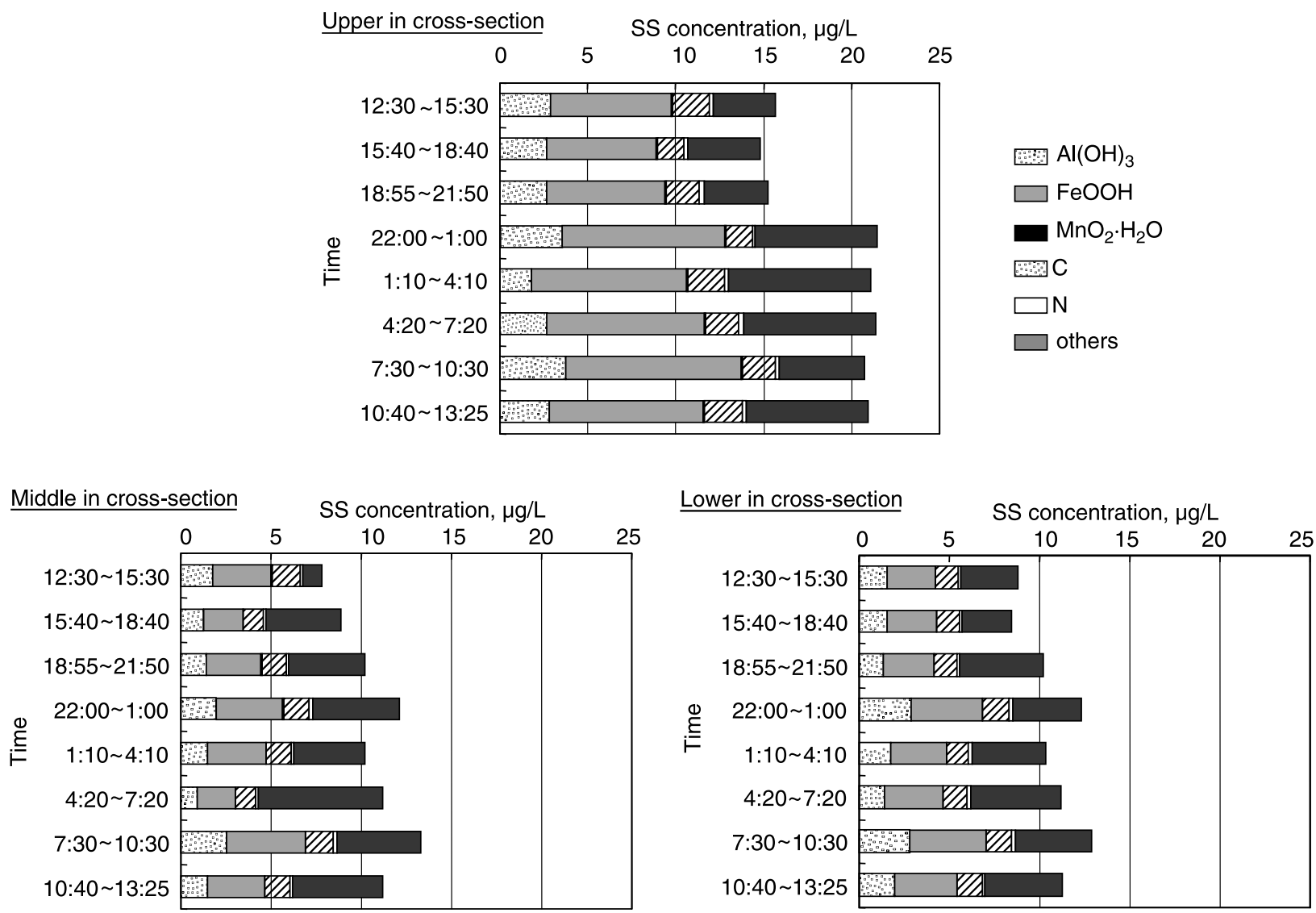

Figure 13 Temporal changes in SS concentrations and their elemental compositions at various vertical locations in the water main cross-section at sampling site NC5 (sampling event S10).

from other cross-section locations because of the small diameters of the water mains). Suspended particle concentrations changed during the day, increasing and then decreasing in the morning and also in the evening, as shown in Figures 15 and 16. These temporal variations of concentrations corresponded to the flow rate variation pattern typically observed for water mains, suggesting the buildup of sediment in the bottom of the water main and resuspension owing to the increased flow rate. At site W2, in particular, an SS concentration of $0.94 \mathrm{mg} / \mathrm{L}$ was recorded at $10 \mathrm{PM}$ (although this value is below the organoleptic concentration and is also less than $5 \mathrm{mg} / \mathrm{L}$, equivalent to the Japanese drinking water quality standard for turbidity). At that time, the filters were briefly clogged (for $15 \mathrm{~min}$ ). It is likely that this sudden rise in SS concentration was caused by explosive resuspension of sediment that had accumulated upstream, close to the sampling point; a cloud of turbid water caused by the sediment resuspension might have flowed into the sampling tube, briefly clogging the filter. In fact, the sediment buildup at the bottom of the water main was observed by a remote videocamera at that point (Japan Water Research Center 2005). Overall, SS concentrations at site W2 were higher than those at the other locations we sampled, likely because

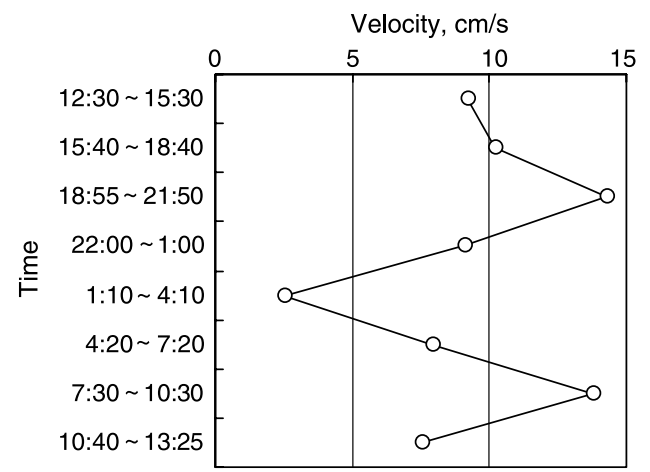

Figure $\mathbf{1 4} \mid$ Variations in flow rates measured $100 \mathrm{~m}$ upstream from the sampling site NC5 (sampling event S10). 


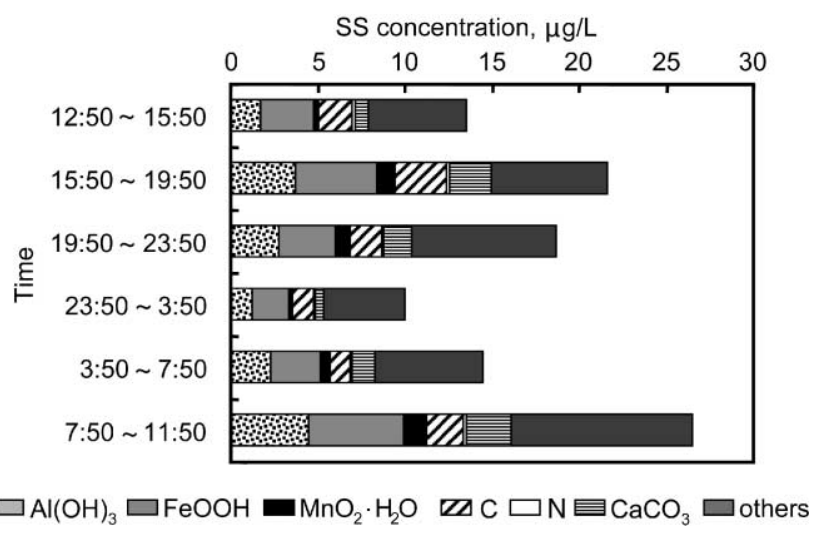

Figure 15 Temporal changes in SS concentrations and their elemental compositions at sampling site W1 (sampling event S11).

the special fittings at W2 were all unlined and thereby could yield more corrosion products.

\section{Cross-sectional changes}

Another interesting finding illustrated in Figure 13 is that the SS concentrations in water flowing through the upper location in the main cross section were higher than those in the middle and lower locations. While SS concentrations in water in the middle and lower locations were always less than $15 \mu \mathrm{g} / \mathrm{L}$, those in the upper location were almost always greater than $15 \mu \mathrm{g} / \mathrm{L}$. The other results for that sampling site (NC5, $2.92 \mathrm{~km}$ ) also showed that SS concentrations in the upper location were higher than $15 \mu \mathrm{g} / \mathrm{L}$

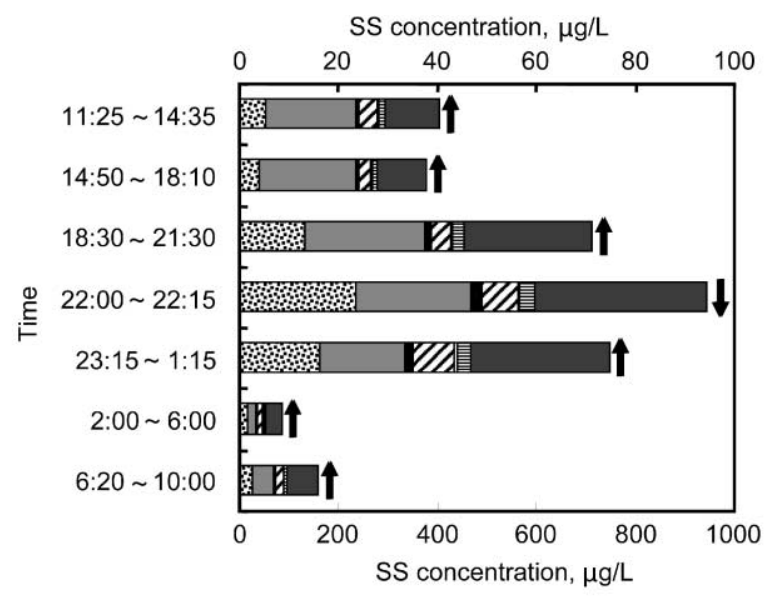

$\square \mathrm{Al}(\mathrm{OH})_{3} \square \mathrm{FeOOH}=\mathrm{MnO}_{2} \cdot \mathrm{H}_{2} \mathrm{Z} \quad \square \mathrm{C} \square \mathrm{N} \boxminus \mathrm{CaCO}_{3} \square$ others

Figure 16 | Temporal changes in SS concentrations and their elemental compositions at sampling site W2 (sampling event S11, arrows indicate corresponding $x$ axis).

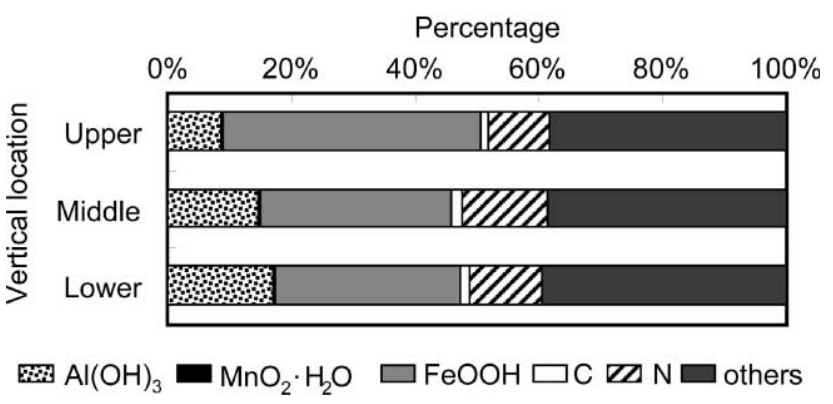

Figure $\mathbf{1 7}$ | Percentages of SS elemental compositions sampled at different vertical locations in the main cross-section at sampling site NC2 (from 1:10 AM to 4:10 AM of sampling event S10).

(Figures 8, 10 and 12), where the sampling events were conduced using Sampling Method 1, which took water from the top of the water stream only. SS iron content and its percentages in the upper location were both higher than those in the middle and lower locations (Figures 13 and 17). Moreover, the percentages of inorganic fractions and iron were higher in the upper location than those in middle and lower locations, respectively (Figure 18). Combining these results with the fact that the water mains at NC5 are either cement-mortar lined or epoxy lined, we deduced that the SS could originate from rusting iron surfaces in the upper part of the pipe cross section, and that these mains are probably connected to fire hydrants that are unlined. Corrosion particles could be produced in the stagnant zone adjacent to the upper part of the water main and then could flow through the upper parts of the main while diffusing crosssectionally. For example, SS concentrations downstream from NC5 decreased to site NC9, $4.67 \mathrm{~km}$ (Figures 8 and $10)$. Water consumption through service pipes could also contribute to the downstream decrease in SS concentrations, because the service pipes tapped into the upper cross-sectional part of the water main.

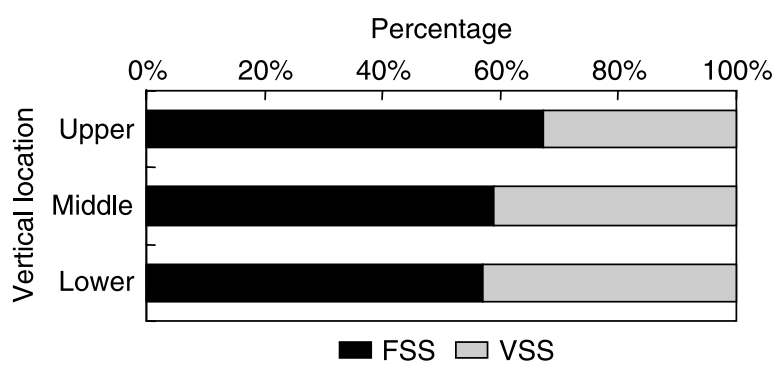

Figure 18 | Percentages of inorganic SS (FSS) and organic SS (VSS) in SS sampled at different vertical locations in the cross-section of the water main at sampling site NC2 (from 1:10 AM to 4:10 AM of sampling event S10). 


\section{CONCLUSIONS}

In this study, we surveyed SS concentrations in water flowing through mains using a method that withdraws water samples directly from a main. The survey revealed the following results:

(1) SS concentrations, the percentages of inorganics in SS and the percentages of iron gradually increased with distance from the trunk main or water distribution tank, i.e. toward the dead end of a water main. The changes in SS concentrations and elemental compositions could be better and more sensitive indicators than residual chlorine concentrations of water quality deterioration in water mains.

(2) The monotonic SS increase toward the dead end of a main was not observed in one water main, where SS concentrations increased in mid-course and then decreased, thereafter gradually increasing toward the main dead end. In mid-course, SS concentrations in this main were higher in the upper location in the main cross section than in the middle and lower locations. The percentages of inorganics and iron were also higher in the upper location. These results suggested the release of corrosion particles that were produced in a stagnant zone, in a fire hydrant or another connection to the upper part of the main.

(3) Temporal variations in SS concentrations were observed in the cross-sectional center and lower locations in the water mains; SS concentrations increased and decreased with flow rate in the mains.

\section{$\overline{\text { ACKNOWLEDGEMENTS }}$}

The Japan Water Research Center partially funded this research; part of this research was conducted as a fundamental study of the EPOCH project of the research center. Nagoya Waterworks \& Sewerage Bureau and
Wakayama Waterworks Bureau are gratefully acknowledged for providing sampling sites and their information. The authors also thank Kubota Corporation for providing technical assistance for Sampling Method 2. The results of this study do not reflect the views of these entities and no official endorsement should be inferred.

\section{REFERENCES}

American Water Works Association 1998 Standard Methods for the Examination of Water and Wastewater, 20th edn. American Public Health Association, American Water Works Association, and Water Environment Federation, Washington, DC.

American Water Works Association 1999 Particle measurement and characterization in drinking water treatment. Proc. Symp. held in Nashville, TN, USA, 28-30 March. AWWA.

Gauthier, V., Barbeau, B., Millette, R., Block, J.-C. \& Prevost, M. 200I Suspended particles in the drinking water of two distribution systems. Wat. Sci. Technol.: Wat. Supply 11(4), 237-245.

Inoue, T., Matsui, Y., Terada, Y., Baba, K. \& Matsushita, T. 2004 Characterization of microparticles in raw, treated, and distributed waters by means of elemental and particle size analyses. Wat. Sci. Technol. 50(12), 71-78.

Japan Water Research Center. 2005 Final Report of EPOCH Research Project. Tokyo, Japan (in Japanese).

Nagoya Waterworks \& Sewerage Bureau. 2005 Personal communication.

Ödman, F., Ruth, T. \& Pontér, C. I999 Validation of a field filtration technique for characterization of suspended particulate matter from freshwater. Part I. Major elements. Appl. Geochem. 14(3), 301-317.

Rodushkin, I., Axelsson, M. D. \& Burman, E. 2000 Multielement analysis of coal by ICP techniques using solution nebulization and laser ablation. Talenta 51, 743-759.

Sly, L. I., Hodgkinson, M. C. \& Arunpairojana, V. 1989 The importance of high aesthetic quality potable water in tourist and recreational areas. Wat. Sci. Technol. 21(2), 183-187.

Sly, L. I., Hodgkinson, M. C. \& Arunpairojana, V. 199o Deposition of manganese in drinking water distribution system. Appl. Environ. Microbiol. 56(3), 628-639.

Wang, C. F., Tu, F. H. \& Jeng, S. L. 1997 Determination of silicon in airborne particulate matter by UV-visible spectrophotometry. Analytica Chimica Acta 342, 239-245. 